\title{
Fishery status of Carangoides bajad and Caranx melampygus (Family Carangidae) from Shalateen Fishing Area, Red Sea, Egypt, based on yield per recruit (Y/R) analysis.
}

Sahar F. Mehanna ${ }^{1}$, Usama M. Mahmoud ${ }^{2}$, Ashraf S. Mohammad ${ }^{1}$.

1. National Institute of Oceanography and Fisheries (NIOF). Egypt,

2. Department of Zoology, Faculty of Science, Assiut University, Assiut, Egypt.

\section{ABSTRACT}

The fishery status of two carangid species; Carangoides bajad and Caranx melampygus from Shalateen fishing area, Red Sea, Egypt has been evaluated. Yield per recruit of the two species as a function of different values of fishing mortality coefficient, age at first capture and natural mortality coefficient was estimated. For $C$. bajad it is found that, the current fishing mortality coefficient $(1.34 / \mathrm{y})$, age at first capture $(0.35 \mathrm{y})$ and natural mortality coefficient $(0.34 / \mathrm{y})$ give a yield of $(304.8 \mathrm{~g})$ per recruit. While for $C$. melampygus, the current fishing mortality coefficient $(1.75 / \mathrm{y})$, age at first capture $(0.35 \mathrm{y})$ and natural mortality coefficient $(0.25 / \mathrm{y})$ give a yield of $(675.63 \mathrm{~g})$ per recruit. Yield per recruit for C. bajad and C. melampygus showed that, the maximum $(\mathrm{Y} / \mathrm{R})$ was obtained at $\mathrm{F}_{\max }=0.5$ and 0.8 for $C$. bajad and $C$. melampygus respectively. For management purposes, the fishing mortality which is related to the fishing effort of $C$. bajad and $C$. melampygus should be reduced by at least $50 \%$ as well as the length at first capture which is related to the mesh size should be raised to the length at first maturity to maintain this valuable fishery.

Keywords: Red Sea, Shalateen, Yield per recruit (Y/R), Carangoides bajad, Caranx melampygus, management.

\section{INTRODUCTION}

In the Egyptian sector of the Red Sea, there are many fishing grounds from which Shalateen fishing area is one of productive areas.At least 10 Carangid species were recorded in Shalateen area from which Carangoides bajad and Caranx melampygus are the most common. Both species are representing an important component of local artisanal catch.

Although, there are many previous studies concerned the biology and dynamics of carangid species along the Egyptian Red Sea, there are no studies dealing with the population dynamics of Carangoides bajad and Caranx melampygus in the Egyptian coasts of Red Sea. Sanders and Morgan (1989) had summarized the stock assessment parameters of Trachurus indicus and Decapterus maruadsi exploited by purse seine fishery in the Red Sea and Gulf of Aden. Mehanna (1999a\&b) assessed the stock status of Trachurus indicus and Decapterus macrosoma from the Gulf of Suez. Mehanna et al. (2005) studied the reproductive dynamics as a fishery management tool for the horse mackerel, Trachurus indicus in the Gulf of Suez, Red Sea, Egypt. Khalifa and Mehanna (2005) estimated a number of precautionary target reference points for carangid fisheries management in the Gulf of Suez, Red Sea, Egypt.ElSherbeny (2015) studied the application of Remote Sensing Techniques, Geographical Information Systems and Analytical Models, for the Pelagic Fisheries Management in the Gulf of Suez, Egypt. Mehanna et al. (2015) investigated growth, mortality and relative yield per recruit of Japanese scad Decapterus maruadsi (Temminck \& Schlegel, 1842) in the Gulf of Suez, Red Sea, Egypt. 
So, the present study will be the first to evaluate the fishery status of Carangoides bajad and Caranx melampygus and suggest some regulatory measurements to manage them in Shalateen fishing area.

\section{MATERIALS AND METHODS}

\section{Study area}

Shalateen port is considered as one of the productive fishing grounds along the Egyptian coasts of Red Sea. It lies in the southern Red Sea, at Elba National Park, $520 \mathrm{Km}$ south of Hurghada, Egypt (Fig. 1). The fishing landing site location latitude (N: $\left.23^{\circ} 09^{\prime} 07.31^{\prime \prime}\right)$ and longitude (E: $\left.35^{\circ} 36^{\prime} 51.14^{\prime \prime}\right)$.

\section{Collection of samples}

A total of 1103 specimens (145-515 mm in SL) of Carangoides bajad and 796 specimens (145-631 mm in SL) of Caranx melampygus were randomly collected monthly from the commercial landings at Shalateen fishing port in the city of Shalateenduring the period from November 2013 to October 2014.

\section{Growth and mortality parameters}

The von Bertalanffy growth parameters $\left(\mathrm{L}_{\infty}, \mathrm{K}\right.$ and $\left.\mathrm{t}_{\mathrm{o}}\right)$ and the total, fishing and natural mortalities were derived from Mohammed et al. (2016) and Mohammed (2016).

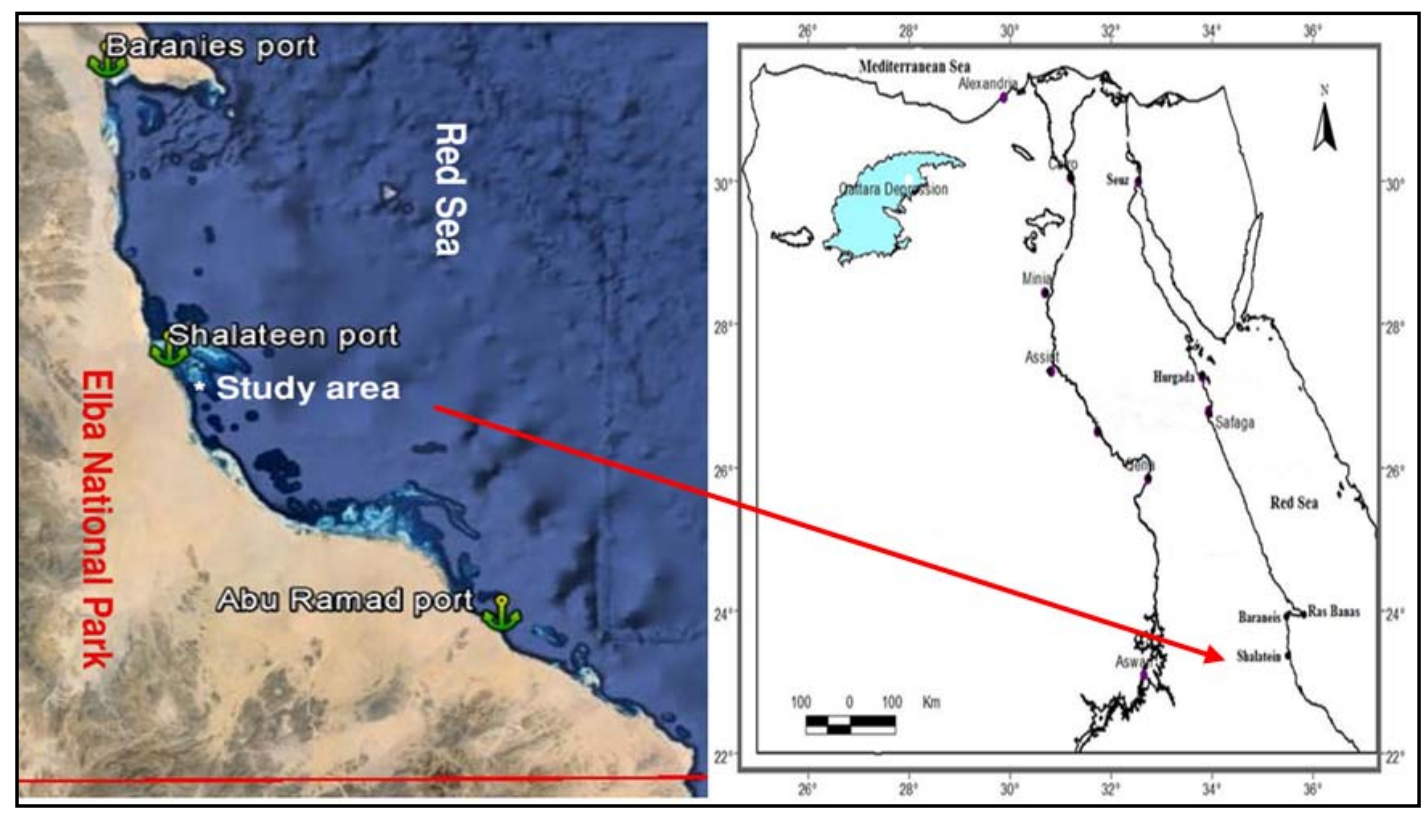

Fig. 1: Egyptian Red Sea map showing the study area

\section{Yield per recruit (Y/R)}

The yield per recruit (Y/R) model of Beverton and Holt (1957) was applied for the two Carangidspecies using Gulland (1969) formula as follows:

Where

$$
\mathbf{Y} / \mathbf{R}=\mathbf{F e}^{-\mathrm{M}(\mathrm{Tc}-\mathrm{Tr})} \mathrm{W}_{\infty}{ }^{*}\left[(\mathbf{1} / \mathrm{Z})-(3 \mathrm{~S} /(\mathrm{Z}+\mathrm{K}))+\left(3 \mathrm{~S}^{2} /(\mathrm{Z}+\mathbf{2 K})\right)-\mathrm{S}^{3} /(\mathrm{Z}+3 \mathrm{~K})\right]
$$

$\mathrm{Y} / \mathrm{R}=$ Yield per recruit

$\mathbf{S}=\mathbf{e}^{-\mathbf{k} \text { (Tc-to) }}$

$\mathrm{K}=$ Von Bertalanffy growth parameter.

$\mathrm{T}_{\mathrm{c}}=$ age at the first capture.

$\mathrm{T}_{\mathrm{r}}=$ age at the recruitment.

$t_{0}=$ age at which the length is nil. 
$\mathrm{W}_{\infty}=$ asymptotic body weight.

$\mathrm{F}=$ fishing mortality coefficient.

$\mathrm{M}=$ natural mortality coefficient.

$\mathrm{Z}=$ total mortality coefficient.

The model was used to calculate $Y / R$ with varying inputs of $F, T_{c}$ and $M$ to assess the effect of fishing effort, mesh size and natural mortality on $\mathrm{Y} / \mathrm{R}$ of the two Carangid species.

\section{RESULTS AND DISCUSSION}

\section{Yield per Recruit (Y/R)}

The input parameters of the two carangid species Carangoides bajad and Caranx melampygus used in the calculations were summarized in Table (1).

Table 1: Population parameters of the Carangoides bajad and Caranx melampygus, from the southern Red Sea of Egypt.

\begin{tabular}{|c|c|c|}
\hline Paramter & Carangoides bajad & Caranx melampygus \\
\hline Lmax & 515 & 631 \\
\hline Loo & 576.88 & 701.08 \\
\hline $\mathrm{K}$ & 0.24 & 0.17 \\
\hline to & -0.86 & -1.013 \\
\hline $\mathrm{Lr}$ & 145 & 145 \\
\hline $\mathrm{Tr}$ & 0.346 & 0.35 \\
\hline $\mathrm{t}$ & 2 & 2 \\
\hline $\mathrm{Lt}$ & 289.5 & 281.00 \\
\hline $\mathrm{Wt}$ & 624 & 608.1 \\
\hline W oo & 5453.60 & 8903.28 \\
\hline $\mathrm{a}(\mathrm{mm})$ & 0.00005 & 0.00004 \\
\hline $\mathrm{a}(\mathrm{cm})$ & 0.0349 & 0.0329 \\
\hline $\mathrm{b}$ & 2.88 & 2.93 \\
\hline L25 & 220.97 & 312.95 \\
\hline L50 (Lc) & 236.81 & 379.41 \\
\hline L75 & 254.36 & 445.87 \\
\hline Tc & 1.34 & 3.57 \\
\hline $\mathrm{Lm}$ & 317.90 & 378.60 \\
\hline Lopt & 391.90 & 470.40 \\
\hline tmax & 8 & 12 \\
\hline $\mathrm{M}$ & 0.34 & 0.25 \\
\hline$E$ & 0.5 & 0.5 \\
\hline$\emptyset^{\prime}$ & 2.91 & 2.93 \\
\hline $\mathrm{F}$ & 1.5 & 1.75 \\
\hline $\mathrm{A}$ & 0.844 & 0.865 \\
\hline $\mathrm{Z}$ & 1.86 & 2 \\
\hline
\end{tabular}

The estimated yield per recruit of C. bajad and C. melampygus as a function of different values of fishing mortality coefficient, age at first capture and natural mortality coefficient are given in Tables 2 and 3 and graphically represented in Figs. 2 and 3.

In general, for the two investigated species, it is clear that, the curve starts at the origin where the yield per recruit is zero when the fishing mortality is zero. Then the yield per recruit increases rapidly as the fishing mortality increases and reached its maximum value, after which the yield per recruit decreases with further increasing of fishing mortality. 
For C.bajad, the current fishing mortality coefficient $(1.34 / \mathrm{y})$, age at first capture $(0.35 \mathrm{y})$ and natural mortality coefficient $(0.34 / \mathrm{y})$ give a yield of $(304.8 \mathrm{~g})$ per recruit with a maximum yield per recruit of $343.5 \mathrm{~g}$ obtained at fishing mortality $(0.5 / \mathrm{y})$. This means that the present level of fishing mortality is much higher than that gives the maximum yield per recruit by about $66.7 \%$ and the reduction of current level of fishing mortality coefficient from 1.5 to $0.5 / \mathrm{y}$ will be associated with an increase in the yield per recruit from 304.8 to $343.5 \mathrm{~g}$ by about $(12.7 \%)$.

To investigate the variation in yield per recruit with changing of age at first capture $\left(T_{c}\right)$ which is related to the estimation of optimum mesh size, the yield per recruit of $C$. bajad was calculated using different values of age at the first capture (Fig.2). The obtained results indicated that the yield per recruit increases with the increase of the age at first capture. The maximum yield per recruit at $\mathrm{T}_{\mathrm{c}}$ equals 0.44 , 1.34 "current value" and 2.24 year were obtained at fishing mortality coefficients 0.3 , 0.5 and $1 / y$ respectively. This means that, the increase of age at the first capture can be associated with the increase of the maximum yield per recruit when the fishing mortality also increases.

Table 2: Yield per recruit of Carangoides bajad and Caranx melampygus as a function of different values of fishing mortality $\mathrm{F}$ and age at first capture Tc.

\begin{tabular}{|c|c|c|c|c|c|c|}
\hline \multirow{2}{*}{$\mathbf{F}$} & \multicolumn{2}{|c}{ Carangoides bajad $\mathbf{Y}$ (g) } & \multicolumn{3}{c|}{ Caranx melampygus $/ \mathbf{R} \mathbf{( g})$} \\
\cline { 2 - 7 } & $\mathbf{T c}=\mathbf{0 . 4 4}$ & $* \mathbf{T c}=\mathbf{1 . 3 4}$ & $\mathbf{T c}=\mathbf{2 . 2 4}$ & $\mathbf{T c}=\mathbf{2 . 3 7}$ & $* \mathbf{T c}=\mathbf{3 . 5 7}$ & $\mathbf{T c}=\mathbf{4 . 7 7}$ \\
\hline $\mathbf{0}$ & 0 & 0 & 0 & 0 & 0 & 0 \\
\hline $\mathbf{0 . 1}$ & 199.8 & 204.3 & 196.4 & 419.32 & 403.27 & 367.53 \\
\hline $\mathbf{0 . 2}$ & 266.0 & 288.6 & 288.9 & 554.91 & 558.03 & 524.23 \\
\hline $\mathbf{0 . 3}$ & $\mathbf{2 8 3 . 4}$ & 324.6 & 336.6 & 601.07 & 626.85 & 603.06 \\
\hline $\mathbf{0 . 4}$ & 281.8 & 339.2 & 362.5 & $\mathbf{6 1 4 . 1 7}$ & 660.01 & 647.20 \\
\hline $\mathbf{0 . 5}$ & 272.7 & $\mathbf{3 4 3 . 5}$ & 377.1 & 614.03 & 676.56 & 673.82 \\
\hline $\mathbf{0 . 6}$ & 261.2 & 342.8 & 385.3 & 608.48 & 684.73 & 690.80 \\
\hline $\mathbf{0 . 7}$ & 249.2 & 339.7 & 389.8 & 600.89 & 688.43 & 702.10 \\
\hline $\mathbf{0 . 8}$ & 237.7 & 335.4 & 392.0 & 592.75 & $\mathbf{6 8 9 . 6 7}$ & 709.86 \\
\hline $\mathbf{0 . 9}$ & 227.1 & 330.7 & 392.95 & 584.74 & 689.52 & 715.33 \\
\hline $\mathbf{1}$ & 217.4 & 325.9 & $\mathbf{3 9 3 . 0 3}$ & 577.15 & 688.58 & 719.27 \\
\hline $\mathbf{1 . 1}$ & 208.6 & 321.2 & 392.6 & 570.09 & 687.20 & 722.16 \\
\hline $\mathbf{1 . 2}$ & 200.7 & 316.7 & 391.8 & 563.59 & 685.60 & 724.30 \\
\hline $\mathbf{1 . 3}$ & 193.6 & 312.5 & 390.8 & 557.63 & 683.90 & 725.90 \\
\hline $\mathbf{1 . 4}$ & 187.2 & 308.5 & 389.7 & 552.18 & 682.17 & 727.10 \\
\hline $\mathbf{1 . 5}$ & $\mathbf{1 8 1 . 4}$ & $\mathbf{3 0 4 . 8}$ & $\mathbf{3 8 8 . 6}$ & 547.18 & 680.45 & 728.02 \\
\hline $\mathbf{1 . 6}$ & 176.1 & 301.4 & 387.4 & 542.59 & 678.78 & 728.71 \\
\hline $\mathbf{1 . 7}$ & 171.3 & 298.2 & 386.3 & 538.38 & 677.17 & 729.23 \\
\hline $\mathbf{1 . 8}$ & 166.9 & 295.2 & 385.1 & $\mathbf{5 3 4 . 5 1}$ & $\mathbf{6 7 5 . 6 3}$ & $\mathbf{7 2 9 . 6 2}$ \\
\hline $\mathbf{1 . 9}$ & 163.0 & 292.4 & 384.0 & 530.94 & 674.16 & 729.90 \\
\hline $\mathbf{2}$ & 159.3 & 289.8 & 382.9 & 527.64 & 672.76 & 730.11 \\
\hline $\mathbf{2 . 1}$ & 156.0 & 287.4 & 381.9 & 524.58 & 671.44 & 730.26 \\
\hline $\mathbf{2 . 2}$ & 152.9 & 285.1 & 380.9 & 521.74 & 670.18 & 730.36 \\
\hline $\mathbf{2 . 3}$ & 150.1 & 283.0 & 379.9 & 519.10 & 668.98 & 730.42 \\
\hline $\mathbf{2 . 4}$ & 147.4 & 281.0 & 379.0 & 516.63 & 667.85 & 730.45 \\
\hline $\mathbf{2 . 5}$ & 145.0 & 279.2 & 378.1 & 514.33 & 666.78 & $\mathbf{7 3 0 . 4 5}$ \\
\hline $\mathbf{2 . 6}$ & 142.7 & 277.4 & 377.3 & 512.18 & 665.76 & 730.43 \\
\hline $\mathbf{2 . 7}$ & 140.6 & 275.8 & 376.5 & 510.16 & 664.79 & 730.40 \\
\hline $\mathbf{2 . 8}$ & 138.6 & 274.2 & 375.7 & 508.26 & 663.87 & 730.35 \\
\hline $\mathbf{2 . 9}$ & 136.8 & 272.8 & 375.0 & 506.48 & 663.00 & 730.30 \\
\hline $\mathbf{3}$ & 135.0 & 271.4 & 374.3 & 504.80 & 662.17 & 730.23 \\
\hline
\end{tabular}



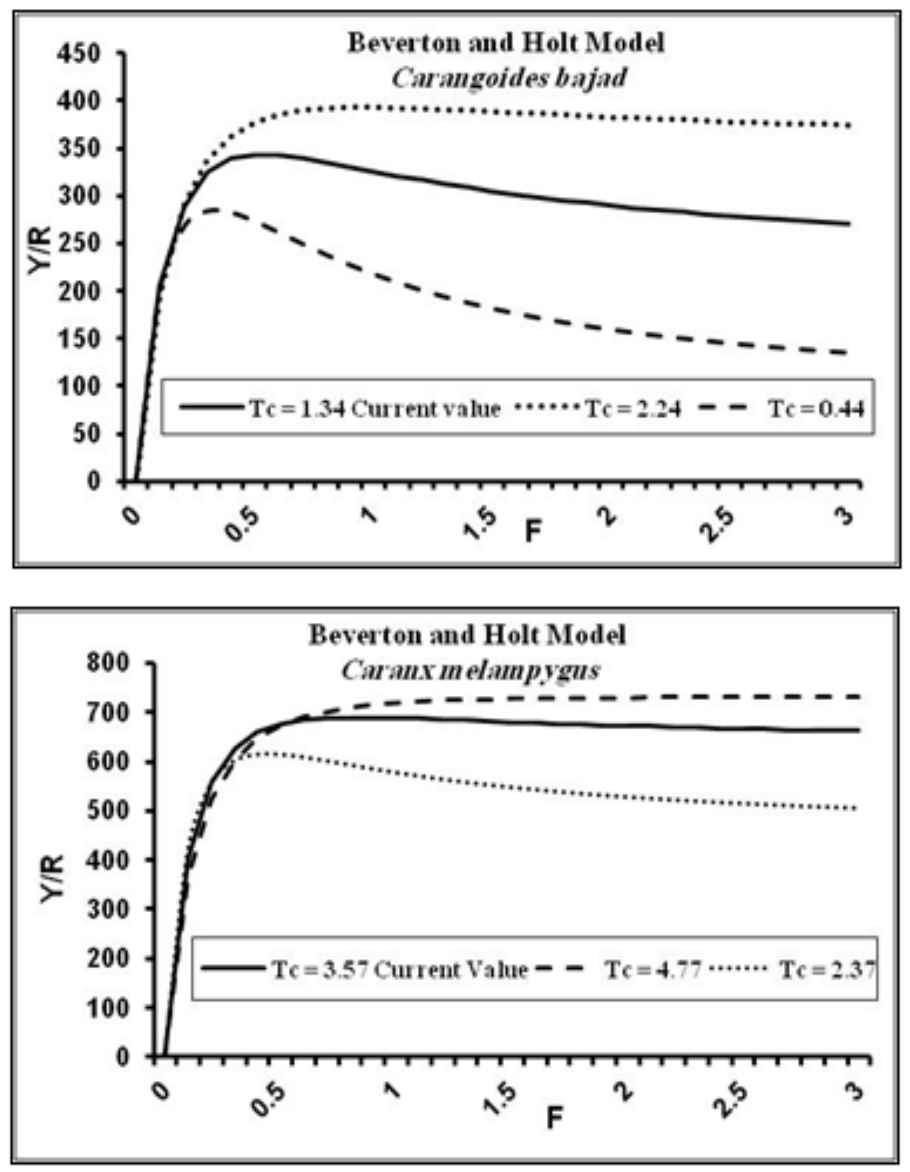

Fig. 2: Yield per recruit (g) of Carangoides bajad and Caranx melampygus collected from the Red Sea, Egypt as a function of fishing mortality (F) and different ages at first capture (Tc).

In addition, to evaluate the effect of changing the natural mortality coefficient (M) on the yield per recruit of C. bajad, the yield per recruit was calculated using different values of natural mortality coefficient $(0.14$ and $0.54 / \mathrm{y})$ with the present level of natural mortality coefficient $(0.34 /$ y) (Table 3 and Fig. 3). The obtained results indicated that, the yield per recruit decreases as the natural mortality coefficient increases. At the current level of fishing mortality coefficient $(1.5 / \mathrm{y})$ and the current age at first capture $(0.35 \mathrm{y})$ with a lower level of natural mortality coefficient $(0.14 / \mathrm{y})$ instead of the current level $(0.34 / \mathrm{y})$, a higher yield per recruit $(371.59 \mathrm{~g})$ would be possible. While with a higher level of natural mortality coefficient $(0.54 / \mathrm{y})$ instead of the current level $(0.34 / \mathrm{y})$, there would be a lower yield per recruit $(250.08 \mathrm{~g})$.

In respect to C. melampygus (Table 2 and Fig. 2), it is found that, the current fishing mortality coefficient $(1.75 / \mathrm{y})$, age at first capture $(0.35 \mathrm{y})$ and natural mortality coefficient $(0.25 / \mathrm{y})$ give a yield of $(675.63 \mathrm{~g})$ per recruit. On the other hand, the maximum yield per recruit $(689.67 \mathrm{~g})$ is obtained at fishing mortality $(0.8 /$ y) with the same values of age at first capture and natural mortality coefficient. This means that the present level of fishing mortality is much higher than that give the maximum yield per recruit by about $(55.6 \%)$ and the reduction of current level of fishing mortality coefficient from 1.8 to 0.8 / y will be associated with an increase in the yield per recruit from 675.63 to $689.67 \mathrm{~g}$ by about $(2 \%)$. 
Table (3): Yield per recruit of Carangoides bajad and Caranx melampygus as a function of different values of fishing and natural mortality $\mathrm{M}$.

\begin{tabular}{|c|c|c|c|c|c|c|}
\hline \multirow[t]{2}{*}{$\mathbf{F}$} & \multicolumn{3}{|c|}{ Carangoides bajadY/R (g) } & \multicolumn{3}{|c|}{ Caranx melampygusY/R (g) } \\
\hline & $M=0.14$ & $* \mathrm{M}=0.34$ & $\mathrm{M}=\mathbf{0 . 5 4}$ & $\mathrm{M}=\mathbf{0 . 1}$ & $* \mathbf{M}=\mathbf{0 . 2 5}$ & $\mathrm{M}=0.4$ \\
\hline $\mathbf{0}$ & 0 & 0 & 0 & 0 & 0 & 0 \\
\hline 0.1 & 249.02 & 204.29 & 167.59 & 653.67 & 403.27 & 248.79 \\
\hline 0.2 & 351.79 & 288.60 & 236.76 & 904.53 & 558.03 & 344.27 \\
\hline 0.3 & 395.73 & 324.65 & 266.33 & 1016.07 & 626.85 & 386.72 \\
\hline 0.4 & 413.44 & 339.17 & 278.25 & 1069.83 & 660.01 & 407.18 \\
\hline 0.5 & 418.69 & 343.48 & 281.78 & 1096.65 & 676.56 & 417.39 \\
\hline 0.6 & 417.85 & 342.79 & 281.22 & 1109.90 & 684.73 & 422.43 \\
\hline 0.7 & 414.04 & 339.66 & 278.65 & 1115.90 & 688.43 & 424.71 \\
\hline 0.8 & 408.84 & 335.40 & 275.15 & 1117.91 & 689.67 & 425.48 \\
\hline 0.9 & 403.09 & 330.68 & 271.28 & 1117.66 & 689.52 & 425.38 \\
\hline 1 & 397.25 & 325.89 & 267.35 & 1116.14 & 688.58 & 424.80 \\
\hline 1.1 & 391.54 & 321.20 & 263.51 & 1113.91 & 687.20 & 423.96 \\
\hline 1.2 & 386.08 & 316.73 & 259.83 & 1111.31 & 685.60 & 422.97 \\
\hline 1.3 & 380.92 & 312.50 & 256.36 & 1108.55 & 683.90 & 421.92 \\
\hline 1.4 & 376.10 & 308.54 & 253.11 & 1105.74 & 682.17 & 420.85 \\
\hline 1.5 & 371.59 & 304.84 & 250.08 & 1102.96 & 680.45 & 419.79 \\
\hline 1.6 & 367.39 & 301.39 & 247.25 & 1100.26 & 678.78 & 418.76 \\
\hline 1.7 & 363.48 & 298.19 & 244.62 & 1097.65 & 677.17 & 417.77 \\
\hline 1.8 & 359.84 & 295.20 & 242.17 & 1095.15 & 675.63 & 416.82 \\
\hline 1.9 & 356.45 & 292.42 & 239.89 & 1092.77 & 674.16 & 415.91 \\
\hline 2 & 353.29 & 289.83 & 237.77 & 1090.50 & 672.76 & 415.05 \\
\hline 2.1 & 350.34 & 287.41 & 235.78 & 1088.35 & 671.44 & 414.23 \\
\hline 2.2 & 347.58 & 285.15 & 233.92 & 1086.31 & 670.18 & 413.45 \\
\hline 2.3 & 345.00 & 283.03 & 232.19 & 1084.38 & 668.98 & 412.72 \\
\hline 2.4 & 342.58 & 281.04 & 230.56 & 1082.54 & 667.85 & 412.02 \\
\hline 2.5 & 340.31 & 279.18 & 229.03 & 1080.80 & 666.78 & 411.36 \\
\hline 2.6 & 338.18 & 277.43 & 227.60 & 1079.15 & 665.76 & 410.73 \\
\hline 2.7 & 336.17 & 275.78 & 226.24 & 1077.58 & 664.79 & 410.13 \\
\hline 2.8 & 334.28 & 274.23 & 224.97 & 1076.09 & 663.87 & 409.56 \\
\hline 2.9 & 332.49 & 272.76 & 223.77 & 1074.67 & 663.00 & 409.02 \\
\hline 3 & 330.80 & 271.38 & 222.63 & 1073.33 & 662.17 & 408.51 \\
\hline
\end{tabular}
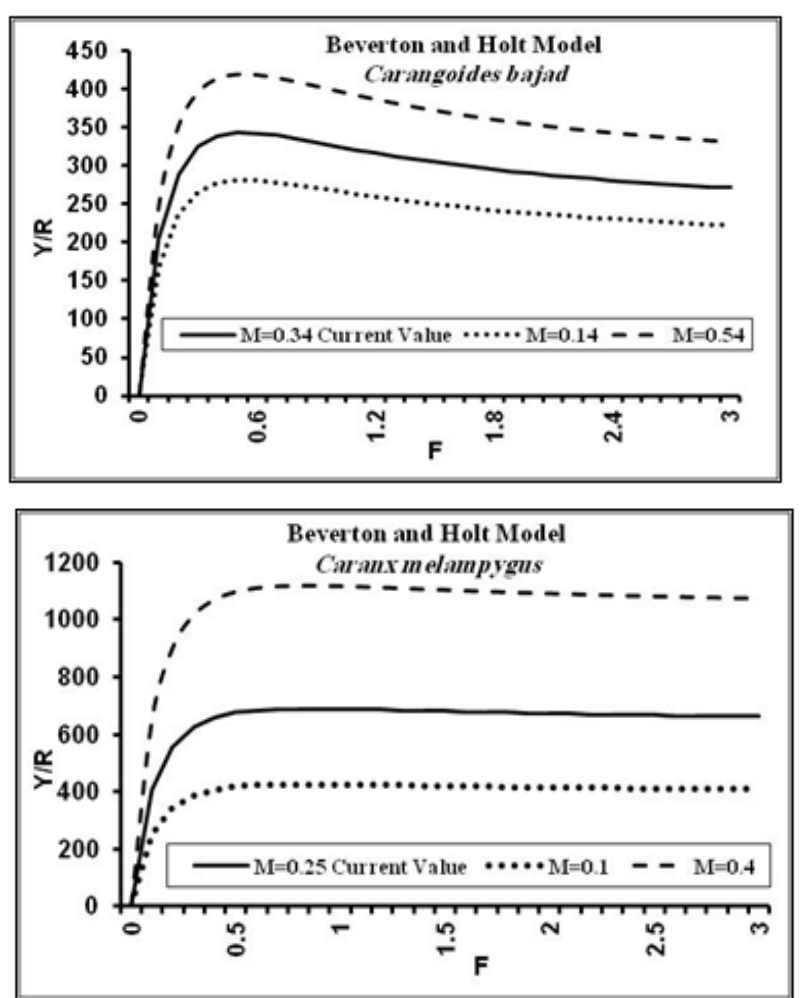

Fig. 3: Yield per recruit (g) of Carangoides bajad and Caranx melampygus collected from the Red Sea, Egypt as a function of fishing mortality (F) and different mortality (M). 
To investigate the variation in yield per recruit with changing of age at first capture $\left(\mathrm{T}_{\mathrm{c}}\right)$, the yield per recruit of $C$. melampygus was calculated using different values of age at the first capture $(2.37$ and $4.77 \mathrm{y})$ with the present level of age at first capture $(0.35 \mathrm{y})$ (Table 2 and Fig. 2$)$. The obtained results indicated that, the yield per recruit increases with the increase of the age at first capture. The maximum yield per recruit at Tc equals 2.37, 3.57 "current value" and 4.77 year were obtained at fishing mortality coefficients $0.4,0.8$ and 2.5 / y respectively. This means that, the increase of the age at the first capture can be associated with the increase of the maximum yield per recruit when the fishing mortality also increases.

In addition, to evaluate the effect of changing the natural mortality coefficient (M) on the yield per recruit of C. melampygus, the yield per recruit was calculated using different values of natural mortality coefficient $(0.1$ and $0.4 / y)$ with the present level of natural mortality coefficient $(0.25 /$ y) (Table 3 and Fig. 3). The obtained results indicated that, the yield per recruit decreases as the natural mortality coefficient increase. At the current level of fishing mortality coefficient $(1.75 / \mathrm{y})$ and the current age at first capture $(0.35 \mathrm{y})$ with a lower level of natural mortality coefficient $(0.1 / \mathrm{y})$ instead of the current level $(0.25 / \mathrm{y})$, a higher yield per recruit $(1117.91 \mathrm{~g})$ would be possible. While with a higher level of natural mortality coefficient $(0.4 / y)$ instead of the current level $(0.25 / \mathrm{y})$, there would be a lower yield per recruit $(425.48 \mathrm{~g})$.

Therefore, it could be concluded that the two carangid stocks in the Shalateen fishing groundare in a situation of overexploitation. To maintain this valuable fish resource, the present level of fishing mortality should be reduced. At the same time, the length at first capture should be increased and the exploitation rate should be reduced below the optimum value.

\section{REFERENCES}

Beverton, R.J.H. and Holt, S.J. (1957). On the dynamics of exploited fish population. U.K. Fish. Invest. Minist. Agr. Fish Food, 19: 533.

El-Sherbeny, A. (2015). Application of Remote Sensing Techniques, Geographical Information Systems and Analytical Models, for the Pelagic Fisheries Management in the Gulf of Suez, Egypt. Ph.D., Thesis, Ain Shams University, Egypt.

Gulland, J.A. (1969). Manual of methods for fish stock assessment. Part (1). Fish population analysis.FAO Man. Fish. Sci. 4:154pp.

Khalifa, U.S. and Mehanna S.F. (2005). Precautionary target reference points (TRPs) for carangid fisheries management in the Gulf of Suez, Red Sea, Egypt.Egyp. J. Aquat. Biol.and Fish., 10 (1): 139-150.

Mehanna, S.F. (1999a). Population dynamics of the round scad Decapterus macrosoma (Bleeker, 1951) in the Gulf of Suez, Egypt. Egyp. J. Aquat. Biol.and Fish., 3(2): 55-68.

Mehanna, S.F. (1999b). Stock assessment of the horse mackerel Trachurus indicus in the Gulf of Suez, Egypt. Indian J. of Fisheries, 46 (4): 327-335.

Mehanna S.F.; Khalifa U.S.A. and Amin A.M. (2005). Reproductive dynamics as a fishery management tool for the horse mackerel, Trachurus indicus (Necrasov, 1966) in the Gulf of Suez, Red Sea, Egypt. African J. Biol. Sci., 1 (1): 27-33.

Mehanna, S.F.; Khalil, M.T.; Ahmed, M.H.M.; El-Kafrawy, S.B. and El-Sherbeny, A.S.H. (2015). Growth, mortality and relative yield per recruit of Japanese scad 
Decapterus maruadsi (Temminck\& Schlegel, 1842) in the Gulf of Suez, Red Sea, Egypt. Egypt. J. Aquat. Biol. \& Fish., 19(1):1-6.

Mohammad, A.S. (2016). Biological Studies, Stock assessment and fisheries management of Carangoides bajad (Forsskål, 1775) and Caranx melampygus (Cuvier, 1833) from the Red Sea, Egypt. Ph.D. Thesis. Zoology Department, Faculty of Science, Assiut University, Egypt.

Mohammad, A.S.; Mehanna, S.F. and Mahmoud, U.M. (2016). Age and Growth Based on the Scale Readings of the Two Carangid Species Carangoides bajad and Caranxmelampygusfrom Shalateen Fishing Area, Red Sea, Egypt. International Conference on Research for Food Security, Natural Resource Management and Rural Development (Tropentag 2016). Vienna, Austria. Accepted article.

Sanders, M. J. and Morgan, G. R. (1989). Review of the fisheries resources of the Red Sea and Gulf of Aden. FAO Fish. Tech. Rep. 304: 1-138.

\section{ARABIC SUMMARY}

تقييم حالة مصايد أسماك البياض؛ كاراتجويدس بياض (Carangoides bajad) و كارانكس ميلامبيجاس (عائلة (لكارنجيدي) من منطقةالثلاتين ، البحر الأحمر، مصر ، بأستخدام (Caranx melampygus) نموذج تحليل الإنتاج لكل جيل (Y/R).

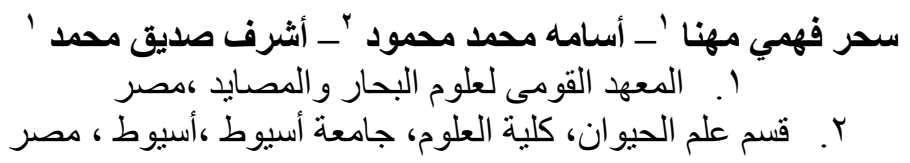

تم تقييم حالة المصايد لنوعين من أسماك عائلة الكارنجيدي (كار انجويدس بياض و و كار انكس

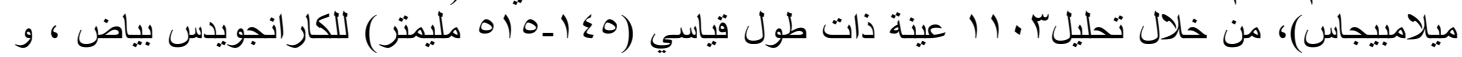

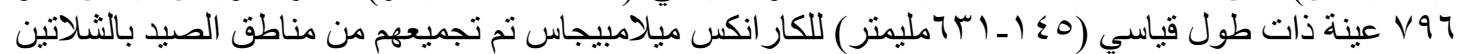

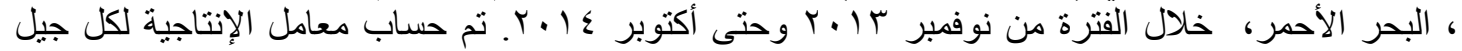

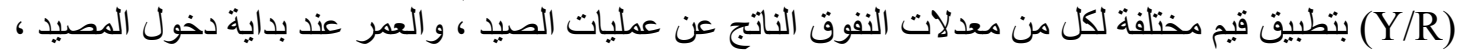
و معدلات النفوق الطبيعى لكل نوع.

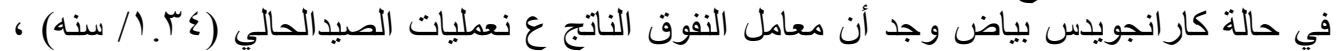

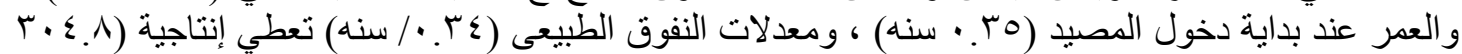

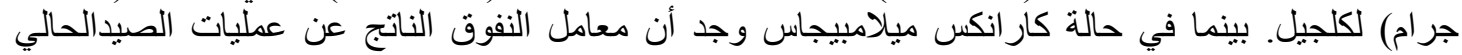

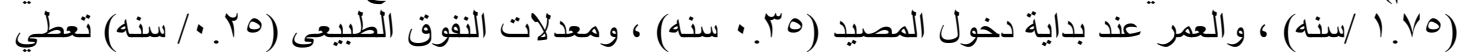

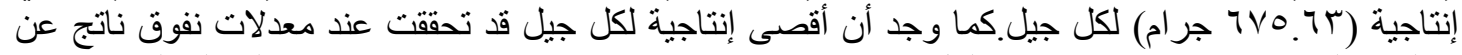

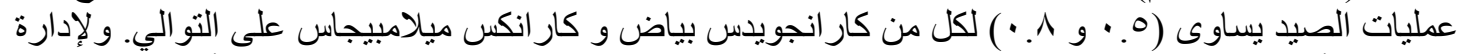

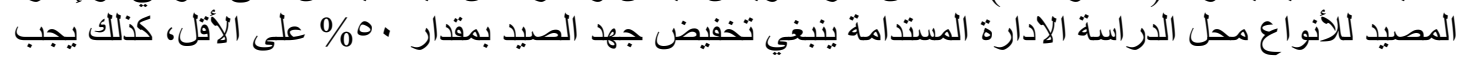

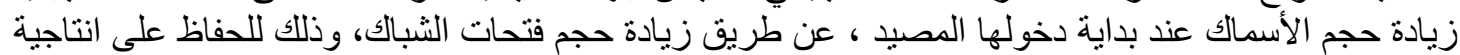

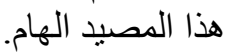

